\title{
Clean bill of health for Sellafield and Dounreay reactors?
}

London

NEw evidence for a theory which attempts to account for the observed higher-thanaverage incidence of childhood leukaemia near nuclear reprocessing plants in the United Kingdom is published in the current issue of The Lancet. Leo Kinlen of the Cancer Research Campaign's epidemiology unit at the University of Edinburgh, suggests that the rapid influxes of population near reprocessing plants are responsible for the increased leukaemia rates, not radiation discharged from the plants, as is popularly believed.

The apparently increased incidence of childhood leukaemia around the two nuclear reprocessing plants in the country - at Sellafield and Dounreay - is no longer much disputed. But there is no accepted explanation for it.

It is well known that people living in isolated places tend to escape common infections, so that when outsiders move

\section{Laboratory accident kills AIDS mice}

\section{Washington}

The first experiment involving transgenic mice containing the genome of HIV, the virus causing AIDS, ended last week when the mice died from accidental overheating.

The transgenic mice were created as an animal model to mimic the symptoms of AIDS in humans. Malcolm Martin, the lead researcher in the experiment being conducted at the US National Institutes of Health (NIH), expected that mice containing HIV genes would produce HIV proteins and perhaps develop AIDS.

Martin received a phone call from a technician at 5:00 a.m. on Monday last week telling him that all but three of his $\mathbf{1 3 0}$ mice were dead. The ventilation in the laboratory housing the mice had been inadvertently cut off for at least seven hours during maintenance work over the weekend. The mice were being kept in a specially designed 30 -foot laboratory glovebox to prevent them from escaping and mating with wild mice, passing on their HIV genes. The glovebox had an autoclave at each end, and the mouse cages inside the box were surrounded by a moat of bleach.

Martin says the shutoff of the glovebox ventilation caused the illumination of an alarm light at NIH's central control centre, but the light was ignored because it was thought to be malfunctioning.

No foul-play is suspected in the accident, but the NIH engineer who neglected to check the building after the warning light went off may be reprimanded. Carol Ezzell in, an epidemic can occur because the indigenous population lacks resistance to the infective agent. And it has been proposed that leukaemia clusters in areas which were isolated and then experience a population influx, such as Sellafield and Dounreay, result from a virus infection to which the indigenous population has not evolved resistance.

Kinlen set out to test this theory by looking for a similarly high incidence of leukaemia mortality in an area which had been isolated before experiencing a sudden population influx, but which lacked any man-made potential source of radiation. In the area identified, Glenrothes in Scotland, Kinlen found an excess in deaths from leukaemia in the under- 25 age group, particularly in the under-fives, when he compared the mortality rates in this area to the national average. Only 3.6 mortalities in the under 25 group were expected and nine were found; in the under- 5 group only 1.5 were expected but 6 were found.

Kinlen says that this work is consistent with the report published in June of the Committee on Medical Aspects of Radiation in the Environment (COMARE). That committee found six cases of childhood leukaemia in the Dounreay area between 1979 and 1984, when only one was expected (see Nature 333, 587; 16 June, 1988). And it said that this evidence, combined with evidence of increased leukaemia incidence at Sellafield, suggested that some feature of the nuclear plants - not necessarily radiation - leads to an increased risk of leukaemia in young people living in the vicinity.

Both BNFL and the United Kingdom Atomic Energy Authority, which runs Dounreay, welcome Kinlen's work, saying that they have long disputed that radiation could be responsible for increased cases of leukaemia around the plants and that this work seems to bear them out. But Simon Boxer, of the pressure group Cumbrians Opposed to a Radioactive Environment (CORE), says that it will take a lot to convince the people living near Sellafield that radioactive discharge is not the culprit. Ray Cartwright of the Leukaemia Research Fund unit at the University of Leeds says the new research is consistent with the hypotheses that his unit is investigating to explain leukaemia clusters. But he says it seems unlikely that a single virus may be responsible; several viruses or a plethora of infectious agents could be involved. He also says there is strong evidence that low-dosage radiation from natural or man-made sources may play an important part.

Christine McGourty

\section{No change at IAEA?}

HANS Blix revealed last week that he will seek a third term as director-general of the International Atomic Energy Agency (IAEA), and it is very likely that the agency's board of governors will choose him when it meets in June. The board's selection must be approved by two-thirds of the $\mathbf{1 1 3}$ member states at the September 1989 general conference. The new term begins in 1990 and lasts four years.

Developing countries belonging to the Group of 77 earlier this year expressed dissatisfaction with Blix, but they have not been able to agree on a candidate to challenge him (see Nature 333, 288; 1988). Blix, a Swede, is only the third director-general in the 31-year history of the IAEA. There has been no director-general from a developing country.

IAEA is an independent body that monitors compliance with the international treaty on nuclear non-proliferation as well as providing technical assistance in nuclear safety, medicine and agriculture and in nuclear energy development.

S.D.

\section{Synchrotron city}

THE world's most powerful synchrotron seems set to be located in a new science city in western Japan. The Science and Technology Agency last week gave the top ranking to Nishiharima technopolis in Hyogo Prefecture, west of Osaka, in a land survey of four potential sites for a giant synchrotron which the agency plans to build by 1995 .

The new synchrotron, which will have a storage ring half a kilometre in diameter and will be able to accelerate electrons up to 8 $\mathrm{GeV}$, will be the world's largest; a $6-\mathrm{GeV}$ European facility is under construction in Grenoble and the United States is building a 7-GeV synchrotron at the Argonne National Laboratory in Illinois. Final cost of the machine is expected to be some $¥ 100,000$ million ( $\$ 800$ million) and the agency has requested $¥ 2,051$ million for its development in fiscal year 1989.

There has been strong competition among local governments to host the new facility because it is expected to help development of high-tech industry, in particular the semiconductor industry. A decision will be made after the completion of additional surveys and an environmental impact assessment. D.S.

\section{Hurd on animals}

A CODE of practice on the use of laboratory animals for scientific purposes in the United Kingdom will be issued by the Home Secretary, Douglas Hurd, by the end of the year. It will provide researchers with guidelines in line with tighter controls on the use of animals introduced in the Animal (Scientific Procedures) Act 1986. The animal procedures committee, which published its first report last week, will help to develop the code of practice under consideration. The code is based on work done by the Royal Society and the Universities Federation for Animal Welfare. 